\title{
Strategic LeAdership, Commitment AND EMPlOYeE MOTIVATION: WHAT INFLUENCES ATTITUDES TOWARDS THE WORKPLACE
}

SARAH BONAU ${ }^{1}$

\section{INTRODUCTION}

This article presents an overview of recent research that has been conducted into how leadership, specifically inspirational leadership, affects employee motivation, and how strategic decision making can be improved by behavioural game theory. Further, studies on which HR measures drive employee commitment, as well as on personal differences and their impact on commitment and satisfaction are discussed. Twenty years after the landmark McKinsey study (Chambers et al., 1998), the "war for talent" still continues. How to increase employees' commitment to the organisation is of central importance to the ongoing policy debate on the development and especially the retention of the workforce. In a time of rapidly changing economic environments, organisations cannot afford to be inefficient and let potential go untapped.

Motivation can be defined as energy and direction that drives cognition or behaviour (Deci \& Ryan, 1985; Ryan \& Deci, 2000). Equally, individuals strive for satisfaction at work as well as personal fulfilment. This article compiles current research findings in the areas of management science and organisational psychology, illustrating how leadership style, strategic decision making, HR measures, and personal differences contribute to a committed and motivated workforce.

The following abstract of this article discusses research on how leadership styles can influence employee motivation and commitment. Next, theoretical concepts of strategic decision making are discussed, specifically behavioural game theory as a practical model compared to traditional game theory. Examples of practical application illustrate how behavioural game theory can inform management decisions. Then, analyses of specific HR measures and their impact on employee commitment are presented. The final abstract presents an analysis of individual differences', specifically intelligence', relation to commitment and job satisfaction.

\section{LEADERSHIP AND EMPLOYEE Motivation}

In a thought piece for the Journal of Management Development, Bonau (2017a) analysed the theoretical aspects of inspirational leadership and presented practical steps for applying the theory. In the context of other leadership theories, Bonau (2017a) defined inspirational leadership and the vision that is central to inspirational leadership. Consequently, Bonau (2017a) contrasted effective leadership behaviour against management actions and then defined main areas leaders should focus on. Bonau (2017a) outlined specific actions to be implemented in these focus areas. Comparing the different perspectives on inspirational leadership theory, Bonau (2017a)

${ }^{1} \mathrm{PhD}$ student, University of Pécs, Faculty of Business and Economics

DOI: 10.14267/RETP2019.04.09 
illustrated that self-awareness and authenticity are the main foundations for inspiring followers and implementing a shared vision. Further, Bonau (2017a) presented a tool for practical implementation that allows leaders to measure different characteristics of inspirational leadership and to assess their progress. In this context, Bonau (2017a) discussed the critical role of authentic behaviour and the challenge of showing the right level of authenticity as a leader. Bonau (2017a) focussed specifically on authentic leadership development, and how organisations must work to avoid over-dependency on inspirational leaders. Beyond contributing to the ongoing debate on leadership styles in management science, the ideas outlined in my paper also serve as a guide for leaders to practise inspirational leadership (Bonau, 2017a).

In a conceptual paper presented at the Ferenc Farkas International Scientific Conference 2018 as a case study of strategic management excellence, Bonau (2018a) analysed how Zara, leading brand of the world's largest clothing retailer Inditex, developed and maintained a competitive advantage by rigorously implementing an innovative corporate strategy based on integrating knowledge management, change management, human resource management, and leadership theory into a wholesome strategy. Its founder Amancio Ortega serves as an example of visionary leadership that is praised globally. The organisation has become a reference point not only for its unique strategy but also because its leaders thought in the long term and designed and optimized operations in line with their strategy. Zara employees feel empowered by organisational structures developed to enhance learning: teamwork is fostered, horizontal communication systems implemented, and decision-making delegated (Gutierrez-Gutierrez, Barrales-Molina \& Kaynak, 2018). In their analysis of small and medium-sized enterprises in Hungary, Richbell, Szerb, and Vitai (2010) recommend leaders to fully involve employees in the day-to-day business activities and in key decisions, in order to increase employee commitment and satisfaction.

A significant body of research has found positive relationships between leadership behaviour and organisational commitment (Yahaya \& Ebrahim, 2016). In leadership studies, inspirational leadership has been found to be particularly relevant for practitioners as it can create a workforce that is more engaged and more committed to the organisation (Bonau, 2017a; Chen, 2002). Cohen (2007) proposed that affective commitment is influenced by variables such as transformational leadership. Bonau (2017a) suggests that inspirational leadership promotes commitment to the organisation as followers feel engaged and empowered. Uniting employees in a shared vision and collective identity based on common values by employing inspirational leadership can create a more committed workforce (Bonau, 2017a).

\section{Strategic Decision Making}

In management, as well as in any other social context, decisions are not solely based on the decision maker's preference, but also on others' preferences and their resulting choices (Leder, Schilbach \& Mojzisch, 2016). Thus, it is in the interest of management science as well as practitioners to understand how strategic decision making can be optimised. In an article for the Journal of Game Theory, Bonau (2017b) examined how behavioural game theory offers valuable alternatives in decision making to traditional game theory as predictions assuming bounded rationality have consistently been found to be more accurate than traditional models over a broad variety of application. When applied correctly, game theory can present a strategic tool for decision making that offers perspectives on how players may act in different settings. However, the 
practical application of game theory has been lagging behind its potential. While standard equilibrium analysis assumes that all agents act rationally, behavioural game theory has extended the theoretic framework of game theory to account for human behaviour in real-world settings. At the core of game theory is the concept that players reason what other players will do, usually by going through iterations of players guessing what other players will do. Building on aspects and concepts from behavioural decision theory, behavioural game theory combines theory and experimental evidence to provide a better model of strategic behaviour in economic, political and social interactions (Bonau, 2017b).

For managers, game theory presents a strategic tool that offers perspectives on how players may act under various circumstances and other information that is valuable for decision making. One point of criticism is that game theory would only present one possible outcome, when in practical terms managers would prefer to be presented with a number of different scenarios when faced with unprecedented, complex situations to decide on (Lindstädt \& Müller, 2010). Real world scenarios which require decision making and strategy building are often messier, more dynamic and less easy to control than the assumptions which build the foundation for classical models like the prisoner's dilemma. Uncertainty cannot be eradicated entirely, and traditional game theory presents various snapshots rather than a fuller picture (Lindstädt \& Müller, 2010).

In reality, most games are characterised in a way that all players do not have every piece of information, i.e., an agent hardly knows the preferences of the other players as well as they do themselves. Thus, such games are called games with incomplete information or asymmetric information (Yildiz, 2012). The hiring process of an organisation is an example of a static game with incomplete information, where each player has a type, namely his or her ability, which neither other players nor the hiring organisation has complete information on. The hiring organisation chooses some players, then each player observes his or her own type, but not the type of the other players, and eventually all players simultaneously decide on their action, only knowing his or her own type (Yildiz, 2012). Consequently, the payoff of a player now depends on the players' actions and types. Such a game is called Bayesian Game, following Harsanyi's framework (Harsanyi, 1968). In Bayesian games, the Nash Equilibrium has the additional characteristic that each type plays a best reply, and that for each player with each possible type, the action is chosen that is optimal based on the conditional beliefs of this particular type against the optimal strategies of all other players of the game (Yildiz, 2012). Following this example, however, in a Bayesian Nash Equilibrium, the worker would shirk regardless of whether his or her type is high ability or low, and the applicant would not be hired, since the hiring organisation would anticipate this behaviour. To solve this conflict, a sequential equilibrium would be required, where players best reply in sequence at every information set, creating subgame-perfect equilibria to maximise their payoff (Yildiz, 2012).

As Bonau (2017b) outlines in the article, behavioural game theory provides a more realistic model for real-life situations. Rather than working on the basis of the homo economicus, the assumption that the human being always strives to maximise his or her profit without considering others, behavioural game theory takes cognitive details and mechanisms into consideration. In practice, the homo economicus is geared to some form of bounded rationality, in which assumptions are simplified and heuristics are deployed due to psychological predispositions, computational deficiencies and time constraints (see Plott \& Smith, 2008), which lead to solutions that 
are satisfactory rather than optimal (Vailati, 2019). Behavioural game theory combines theory and experimental evidence to provide a model for better understanding strategic behaviour in economic, political and social interactions, building on aspects and concepts from behavioural decision theory (Crawford, 2013). To analyse problems from a behavioural perspective, the decisions of other players can be predicted either by thinking or learning. When there is a lack of prior experience with analogous games to learn the likely behaviour of the other players, the analysis has to rely on strategic thinking (Crawford, 2013).

In criticism of behavioural game theory, it can be argued that the variety of options in which behaviour can be adjusted based on the situational framework is too broad to manage and that the adjustments required would produce a model that is not generalisable. However, particularly the Cognitive Hierarchy Model provides a model which takes bounded rationality and heterogeneous thinking into consideration, while it also is as generally applicable as equilibrium models. More than a hundred experiments and various field studies of behavioural game theory models have shown that models which consider bounded rationality outperform the predictions of equilibrium strategies (see Camerer, Ho \& Chong, 2015). The broad spectrum of areas of application, including managerial strategies (Goldfarb \& Xiao, 2011), lead Bonau (2017b) to infer that behavioural game theory models provide an advantage over traditional models.

\section{Drivers of Employee Commitment}

Considerable interest has risen in the mid-1980s in the idea that companies can improve their performance when they increase their employees' commitment through measures of human resource management (Bryson \& White, 2008). In the 1990s the focus of organisations turned to human resource management more strategically, with the realisation that the human asset should be aligned more closely with the organisation's objectives (Wood \& Kispál-Vitai, 2014). A number of studies have shown that HR practices are related to various performance measures such as Return on Equity, Market Value, or operational measures (see Wright \& Kehoe, 2008). Understanding the linkage between different HR measures, employees' job satisfaction, their commitment to the organisation, and organisational outcomes or performance is crucial for managers in the interest of their staff as well as their stakeholders. In a study published in the International Journal of Employment Studies, Bonau (2018b) explored the determinants of three measures of employee commitment - shared values with the organisation, loyalty towards the organisation, and pride in working for the organisation - using self-reported employee data from the 2011 UK Workplace Employment Relations Study which covers 21,981 employees. The benefits of having a workforce that is strongly committed to the organisation have been established by a substantial body of evidence (see Meyer \& Maltin, 2010). To predict employees' turnover, absenteeism (Meyer, Stanley, Herscovitch, \& Topolnytsky, 2002; Gellatly \& Hedberg. 2016), performance (Cooper-Hakim \& Viswesvaran, 2005; Riketta, 2002), and well-being (Meyer \& Maltin, 2010), commitment has been used as an antecedent (Mathieu \& Zajac, 1990). Organisational outcomes such as sales and profitability as well as turnover intentions have also been found to be affected by the workforce's commitment (see Koh \& Boo, 2004). The negative implications of higher absenteeism and turnover rates for organisations have been widely reported (Jiang, Lepak, Hu \& Baer, 2012; Glebbeek \& Bax, 2004; Morrow \& McElroy, 2007). Absence and churn rates cost organisations in productivity and morale through disruptions, as well as in additional 
hiring and training costs (Koh \& Boo, 2004; Hausknecht \& Trevor, 2011). Commitment to the organisation can be displayed in various different facets and behaviours (Klein, Molloy \& Brinsfield, 2012). Organisational Citizenship Behaviour, a set of behaviours in the workplace which support the organisation's members or environment, can be considered a materialisation of employee attitudes such as organisational commitment (Chun, Shin, Choi \& Kim, 2013).

For this study, Bonau (2018b) analysed the data set first using an explanatory model, as well as a predictive analysis in the second step. Bonau (2018b) then contrasted the results of the two different types of analysis. The statistical, explanatory model is tailored to test causal hypotheses, while the predictive model is best applied for predictive power (Shmueli \& Koppius, 2011). As such, findings from the explanatory analysis contribute to the existing understanding of the conceptualisation of commitment. The predictive analysis can help practitioners in identifying specific HR methods that will create and foster a committed workforce. Bonau (2018b) explored the determinants of three measures of employee commitment - shared values with the organisation, loyalty towards the organisation, and pride in working for the organisation - using self-reported employee data from the 2011 UK Workplace and Employee Relations Survey that covers 21,981 employees. The basic unit of analysis in the survey was the workplace. The stratified random sample of 2,680 workplaces is representative of British workplaces with five or more employees from seventeen industry sectors (UK Data Archive, 2013). As such, this population accounts for around $90 \%$ of all employees and 35\% of all workplaces in Britain (Wanrooy et al., 2013).

Bonau (2018b) analysed the level of employee commitment using twelve variables which represent employees' attitudes towards the job, the workplace, and working at the workplace, including satisfaction with management, HR measures, or training. Bonau (2018b) contrasted outcomes of descriptive modelling using ordered probit analysis, conducting with the analysis software R, with predictive modelling outcomes in the form of decision tree models using Gini-index and Gain-ratio splitting measures, conducted with the software platform RapidMiner. Bonau (2018b) then tested the determinants for their support of theories on motivation in connection with commitment, specifically Self-Determination Theory (SDT: Deci \& Ryan, 1985; Ryan \& Deci, 2000).

Descriptive and predictive analyses confirmed a set of drivers of commitment that can be grouped into two types: measures that encourage employee involvement, and aspects that foster further development of the employee's skills (Bonau, 2018b). Bonau (2018b) found pay satisfaction to be negatively correlated to measures of commitment. A striking finding of this analysis indicates that amount of pay erodes employee commitment (Bonau, 2018b). Further, Bonau (2018b) found that variables representing the active and autonomous engagement of employees, such as having influence over the job, being involved in decision-making processes, and being given scope for own initiative, had an influence on all three measures of commitment. These findings are in line with theories of motivation, specifically with the SDT concepts (Deci \& Ryan, 1985; Ryan \& Deci, 2000). SDT as a framework has been found to be compatible with the concept of organisational commitment (Meyer, Becker \& Vandenberghe, 2004; Meyer \& Maltin, 2010). In this analysis, specifically the needs for autonomy and for relatedness were driving commitment to the organisation (Bonau, 2018b). Satisfaction with the training received, as well as with the options to develop one's skills, and management that is encouraging further development of their employee's skills as predictors for commitment are supported by the SDT component of need for competence. Analysing specifically a higher education setting, Kispál-Vi- 
tai (2018) found that a mixture of extrinsic and intrinsic motivation needs to be present to have a maximum impact. IT tools and system can be useful in facilitating and supporting especially the need for autonomy and the need for competence (Kispál-Vitai, 2018).

\section{Personal differences and Attitudes towards the workplace}

A research project presented at the 19th Annual Conference of the International Society for Intelligence Research investigated how the personal attribute of intelligence influences the development of individual levels of commitment to the organisation, and how this relationship is affected by overall job satisfaction (Bonau, 2018c). The outline presents the concept of organisational commitment (OC), specifically its three components affective commitment, continuance commitment and normative commitment, and job satisfaction as a correlate of organisational commitment in the context of personal characteristics. The article discusses further motivational aspects that are hypothesized to influence the development of OC. The data collected through an online survey ( $n=2,656$ ) was analysed with exploratory factor analysis using the principal component method to test the significance of the four factors of the underlying concepts (affective commitment, continuance commitment, normative commitment and job satisfaction), followed by confirmatory factor analysis to test the fitness of the structures, using IBM SPSS Amos. Hierarchical multiple regression analyses were carried out using IBM SPSS to determine interactions among different independent variables. Further, qualitative results drawn from focus group discussions were added to validate the findings from the quantitative research. The findings suggest that with the given sample, differences between the high-IQ group and the control group have been observed on the levels of commitment that were reported (Bonau, 2018c). While these differences could not all be confirmed at a statistical significance of 95\%, levels of affective commitment, of continuance commitment and of normative commitment could be found to be lower among employees in the right tail of the IQ bell curve. Higher self-efficacy among high-IQ members could explain some parts of these differences. A positive relationship between job satisfaction and OC overall, as well as a positive relationship between high IQ and job satisfaction, indicates that (extrinsic) job satisfaction would have a moderating effect on the (negative) relationship between high IQ and OC (Bonau, 2018c). Further findings specific to the high IQ group were discussed. The findings from this research and their interpretations can inform management practitioners as well as individuals currently employed or seeking new employment. Beyond confirming the reliability of the concept of OC through factor analysis, this study contributed to the understanding of how individual differences such as cognitive ability help develop different components of commitment to the organisation. Additionally, this research project illustrated how theories on motivational states such as self-efficacy and SDT can be linked to the different components of OC and intelligence. Further, the findings expand the existing understanding of the relationship between job satisfaction and the three components of OC.

\section{Conclusion}

This outline illustrated how inspirational leadership can create a more committed workforce by providing a feeling of empowerment and engagement. The discussion on strategic decision making has made it apparent that behavioural game theory provides more accurate predictions 
of human behaviour in decision making compared to traditional game theory, and can help managerial decision in areas such as personnel hiring, or business strategy. Findings of the analysis of HR measures and their impact on employee commitment show two types of influence: HR measures which encourage employee involvement, and those that foster the development of the employee's skills. IQ was found to potentially have a negative relation with organisational commitment. The SDT components of need for autonomy, need for relatedness, and need for competence are considered to explain how the different aspects of the working environment influence employees' attitudes towards their job and organisation.

\section{REFERENCES}

Bonau, S. (2017a). How to become an Inspirational Leader, and what to avoid. Journal of Management Development, 36(5), 614-625.

Bonau, S. (2017b). A case for behavioural game theory. Journal of Game Theory, 6(1), 7-14.

Bonau, S. (2018a). Fashion brand Zara as an example of excellence in strategic management. In: Dobrai Katalin, László Gyula, Sipos Norbert (ed.) Farkas Ferenc Nemzetközi Tudományos Konferencia 2018 [Ferenc Farkas International Scientific Conference 2018]. University of Pecs, pp. 598-613. ISBN: 978-963-429-238-8

Bonau, S. (2018b). Drivers of Employee Commitment: Evidence from the 2011 Workplace Employment Relations Survey of Employees. International Journal of Employment Studies, 26(1), 40-61.

Bonau, S. (2018c). Too smart to commit? Effects of personal characteristics on organisational commitment and job satisfaction: Evidence from a high-IQ network. 19th Annual Conference of the International Society for Intelligence Research (Poster presentation), Edinburgh/ UK, July 2018.

Bryson, A., \& White, M. (2008). Organizational Commitment: Do Workplace Practices Matter?, CEP Discussion Paper No. 0881, London School of Economics and Political Science.

Camerer, C. F., Ho, T. H., \& Chong, J. K. (2015). A psychological approach to strategic thinking in games. Current Opinion in Behavioral Sciences, 3, 157-162.

Chambers, E.G., Foulan, M., Handfield-Jones, H., Hankin, S. M., \& Michaels, E. G. (1998). War for talent. The McKinsey Quarterly, 3, 44-57.

Chen, L. Y. (2002). An examination of the relationship between leadership behavior and organizational commitment at steel companies. Journal of Applied Management and Entrepreneurship, 7(2), 122-142.

Chun, J. S., Shin, Y., Choi, J. N., \& Kim, M. S. (2013). How does corporate ethics contribute to firm financial performance? The mediating role of collective organizational commitment and organizational citizenship behavior. Journal of Management, 39(4), pp. 853-877.

Cohen, A. (2007). Commitment before and after: An evaluation and reconceptualization of organizational commitment. Human Resource Management Review, 17(3), 336-354.

Cooper-Hakim, A., \& Viswesvaran, C. (2005). The construct of work commitment: testing an integrative framework. Psychological Bulletin, 131(2), pp. 241-259.

Crawford, V. P. (2013). Introduction to behavioural game theory and game experiments. University of Oxford, Michaelmas Term 2013. Retrieved from http://econweb.ucsd.edu/ vcrawfor/ BGTIntroductionSlides13.pdf 
Deci, E. L., \& Ryan, R. M. (1985). Intrinsic motivation and self-determination in human behavior. New York: Plenum Publishing Co.

Gellatly, I. R., \& Hedberg, L. M. (2016). Employee turnover and absenteeism. In J. P. Meyer (Ed.), Handbook of Employee Commitment (pp. 195 - 207). Cheltenham, UK: Edward Elgar Publishing.

Glebbeek, A. C., \& Bax, E. H. (2004). Is high employee turnover really harmful? An empirical test using company records. Academy of Management Journal, 47(2), pp. 277-286.

Goldfarb, A., \& Xiao, M. (2011). Who thinks about the competition? Managerial ability and strategic entry in US local telephone markets. The American Economic Review, 101(7), 3130-3161.

Gutierrez-Gutierrez, L. J., Barrales-Molina, V., \& Kaynak, H. (2018). The role of human resourcerelated quality management practices in new product development: A dynamic capability perspective. International Journal of Operations \& Production Management, 38(1), 43-66.

Harsanyi, J. C. (1968). Games with incomplete information played by Bayesian players, I-III. Part I. The basic model. Management Science, 14(3), 159-182.

Hausknecht, J. P., \& Trevor, C. O. (2011). Collective turnover at the group, unit, and organizational levels: Evidence, issues, and implications. Journal of Management, 37(1), pp. 352-388.

Jiang, K., Lepak, D. P., Hu, J., \& Baer, J. C. (2012). How does human resource management influence organizational outcomes? A meta-analytic investigation of mediating mechanisms. Academy of Management Journal, 55(6), pp. 1264-1294.

Kispál-Vitai, Z. (2018). The Relationship Between Student Motivation and New Media Usage in Teaching Organizational Behavior and HRM in a Central-East European Country. In M. Überwimmer, R. Füreder, M. Gaisch (Eds.), Cross-Cultural Business Conference 2018: Proceedings (pp. 189-202). Aachen, Germany: Shaker Verlag.

Klein, H. J., Molloy, J. C., \& Brinsfield, C. T. (2012). Reconceptualizing workplace commitment to redress a stretched construct: Revisiting assumptions and removing confounds. Academy of Management Review, 37(1), pp. 130-151.

Koh, H. C., \& Boo, E. F. H. (2004). Organisational ethics and employee satisfaction and commitment. Management Decision, 42(5), pp. 677-693.

Leder, J., Schilbach, L., \& Mojzisch, A. (2016). Strategic decision-making and social skills: Integrating behavioral economics and social cognition research. International Journal of Financial Studies, 4(4), 22.

Lindstädt, H., \& Müller, J. (2010). Making game theory work for managers. McKinsey Quarterly, 1-9.

Mathieu, J. E., \& Zajac, D. M. (1990). A review and meta-analysis of the antecedents, correlates, and consequences of organizational commitment. Psychological Bulletin, 108(2), pp. 171194.

Meyer, J. P., Becker, T. E., \& Vandenberghe, C. (2004). Employee Commitment and Motivation: A Conceptual Analysis and Integrative Model. Journal of Applied Psychology, 89(6), 9911007.

Meyer, J. P., \& Maltin, E. R. (2010). Employee commitment and well-being: A critical review, theoretical framework and research agenda. Journal of Vocational Behavior, 77(2), 323-337.

Meyer, J. P., Stanley, D. J., Herscovitch, L., \& Topolnytsky, L. (2002). Affective, continuance, and normative commitment to the organization: A meta-analysis of antecedents, correlates, and consequences. Journal of Vocational Behavior, 61(1), pp. 20-52. 
Morrow, P., \& McElroy, J. (2007). Efficiency as a mediator in turnover-organizational performance relations. Human Relations, 60(6), pp. 827-849.

Plott, C. \& V. Smith. (2008). Handbook of Experimental Economics Results. Elsevier: Amsterdam, Netherlands.

Richbell, S., Szerb, L., \& Vitai, Z. (2010). HRM in the Hungarian SME sector. Employee Relations, $32(3), 262-280$.

Riketta, M. (2002). Attitudinal organizational commitment and job performance: a meta-analysis. Journal of Organizational Behavior, 23(3), pp. 257-266.

Ryan, R. M., \& Deci, E. L. (2000). Self-determination theory and the facilitation of intrinsic motivation, social development, and well-being. American Psychologist, 55(1), 68-78.

Shmueli, G., \& Koppius, O. R. (2011). Predictive analytics in information systems research. MIS Quarterly, 35(3), pp. 553-572.

UK Data Archive (2013). The Design and Administration of the 2011 Workplace Employment Relations Survey, available from the UK Data Service.

Vailati, E. (2019). Behavioral Game Theory. Southern Illinois University. Retrieved from http:// www.siue.edu/ evailat/gt-behavior.htm

Wanrooy, B. V., Bewley, H., Bryson, A., Forth, J., Freeth, S., Stokes, L., \& Wood, S. (2013). The 2011 workplace employment relations study: First findings. Department for Business, Innovation and Skills.

Wood, G., \& Kispál-Vitai, Z. (2014). Strategic Human Resource Management. In G. Rees \& P. E. Smith (Eds.), Strategic Human Resource Management: An International Perspective (pp. 72-100). London, UK: Sage Publications.

Wright, P. M., \& Kehoe, R. R. (2008). Human resource practices and organizational commitment: A deeper examination. Asia Pacific Journal of Human Resources, 46(1), pp. 6-20.

Yahaya, R., \& Ebrahim, F. (2016). Leadership styles and organizational commitment: literature review. Journal of Management Development, 35(2), 190-216.

Yildiz, M. (2012). 14.12 Economic Applications of Game Theory, Fall 2012. Massachusetts Institute of Technology: MIT OpenCourseWare, Retrieved from http://ocw.mit.edu. License: Creative Commons BYNCSA. 